\title{
Pathogenic effects of Vibrio alginolyticus on larvae and postlarvae of the red abalone Haliotis rufescens
}

\author{
Casandra Anguiano-Beltrán ${ }^{1}$, Ricardo Searcy-Bernal ${ }^{1, *}$, M. Leonardo Lizárraga-Partida ${ }^{2}$ \\ ${ }^{1}$ Instituto de Investigaciones Oceanológicas, Universidad Autónoma de Baja California, Apartado Postal 453, Ensenada, \\ B.C. 22860, México \\ ${ }^{2}$ Centro de Investigación Científica y Educación Superior de Ensenada, Apartado Postal 2732, Ensenada, \\ B.C. 22860 , México
}

\begin{abstract}
The pathogenicity of Vibrio alginolyticus on Haliotis rufescens veliger larvae and $4 \mathrm{~d}$ old postlarvae was tested in small-scale static bioassays with different bacterial concentrations $\left(10^{2}\right.$ to $10^{6}$ cells $\mathrm{ml}^{-1}$ ). Larval and postlarval survival were evaluated at 24 and $48 \mathrm{~h}$. Results suggest that $V$ alginolyticus can cause massive mortality in larvae of $H$. rufescens within $24 \mathrm{~h}$ at concentrations above $10^{5}$ cell $\mathrm{ml}^{-1}$, while a concentration of $10^{6}$ cell $\mathrm{ml}^{-1}$ is required to produce the same effect in abalone postlarvae. The potential application of these results to hatchery conditions is discussed.
\end{abstract}

KEY WORDS: Abalone - Pathology · Vibrio alginolyticus

\section{INTRODUCTION}

Molluscs, both in culture and natural populations, can be severely affected by a wide range of microbial diseases. Vibrio spp. are considered some of the most common and serious bacterial pathogens in hatcheries and can cause massive mortalities of larval, postlarval and juvenile stages of several molluscs (Elston 1984, Tubiash \& Otto 1986, Sindermann 1988).

Walne (1958) reported the first evidence of a pathogenic effect of bacteria on bivalve larvae. Since then, several studies have been conducted with different bivalve species to address the role of bacteria in hatcheries. Most of these studies were descriptive and observational (Tubiash et al. 1965, Brown 1973, Murchelano et al. 1975, Lodeiros et al. 1987, Jeanthon et al. 1988, Mialhe et al. 1992). Only a few experimental studies on bacterial pathogenicity (e.g. involving the manipulation of bacterial concentrations) have been reported (Guillard 1959, Elston \& Leibovitz 1980, Brown 1981, Jeffries 1982, Douillet \& Langdon 1993, Moore et al. 1993, Anguiano-Beltrán 1996).

In abalone Haliotis spp., descriptive studies have reported Vibrio-related mortalities during larval (Ebert

\footnotetext{
- Addressee for correspondence.

E-mail: casandra@faro.ens.uabc.mx
}

\& Houk 1984) and juvenile culture (Elston 1983, Elston \& Lockwood 1983, Dixon et al. 1991). This contribution represents the first experimental study on the pathogenic effect of different bacterial concentrations of $V$. alginolyticus on larvae and postlarvae of the red abalone $H$. rufescens, which is the most important gastropod for commercial aquaculture in the USA and México (Ebert 1992, Pérez-Muñoz 1995).

\section{MATERIALS AND METHODS}

Early veliger larvae of Haliotis rufescens were obtained from a commercial hatchery (Abulones Cultivados, Eréndira, Baja California, México). Further larval culture, settlement induction with gamma-aminobutyric acid ( 7 d after fertilization) and postlarval culture were performed at the University of Baja California facilities at Ensenada, B.C., following methods described elsewhere (Searcy-Bernal et al. 1992). Exogenous food is not required and was not provided during abalone larval development (Ebert \& Houk 1984) but a cultured benthic diatom (Navicula incerta) was added as postlarval food $1 \mathrm{~d}$ after settlement. The small-scale bioassays reported here were performed in sterile 6-well tissue culture plates (Corning) with $6 \mathrm{ml}$ of autoclaved seawater per well (out of $10 \mathrm{ml}$ total capacity). 
A reference strain (Gherna \& Pienta 1992) of Vibrio alginolyticus (ATCC 17749) was plated on Zobell media and incubated at $26^{\circ} \mathrm{C}$ for $24 \mathrm{~h}$. Bacteria were then collected, diluted and inoculated to obtain 6 treatment concentrations $\left(0,10^{2}, 10^{3}, 10^{4}, 10^{5}\right.$ and $10^{6}$ cells $\mathrm{ml}^{-1}$ ) in the wells of each of 5 plates with the aid of a spectrophotometric calibration curve at $600 \mathrm{~nm}$ (Anguiano-Beltrán 1996). The first treatment (without bacteria added) was considered as a control. A completely randomized block experimental design was followed considering each plate as a block into whose wells the 6 treatments were randomly assigned. The initial concentrations of bacteria after inoculation were determined by enumeration on thiosulphate citrate bile salts sucrose (TCBS) medium.

Five-day old iarvae or 4 da old postiarvae (i i d after fertilization) of the same batch were added to the plates at approximate densities of $5 \mathrm{ml}^{-1}$ and $2 \mathrm{~cm}^{-2}$ respectively. These initial densities were verified by microscopic observations and the differences among wells were less than $10 \%$. Abalones were washed 5 times with UV-treated $0.45 \mu \mathrm{m}$ filtered seawater before the trials. Larval and postlarval survival (\%) was estimated under a dissecting microscope $(100 \times)$ after 24 and $48 \mathrm{~h}$. Organisms that did not show any movement or activity for 5 min were considered dead. Temperature was maintained at 16 to $18^{\circ} \mathrm{C}$, water was not changed and postlarvae were not fed during the experimental period.

Treatment and block effects were tested by analysis of variance including the partition of sum of squares due to linear and quadratic effects. Second-order polynomial regressions were used to estimate the bacterial concentrations associated with a $50 \%$ mortality (referred to as threshold concentration). These analyses were performed on raw data and after a conventional arcsine transformation for percentages (Damon \& Harvey 1987) These 2 approaches yielded similar statistical inferences, but only results based on raw data are given below since these can be easily interpreted.

\section{RESULTS}

The pattern of larval survival in different bacterial concentrations at 24 and $48 \mathrm{~h}$ is presented in Fig. 1. In both cases treatment effects were highly significant ( $\mathrm{p}<$ 0.001 ) and no block effect was detected (Tables $1 \& 2$ ). At the highest level of Vibrio alginolyticus $\left(10^{6}\right.$ cells $\mathrm{ml}^{-1}$ ) all abalone larvae died within $24 \mathrm{~h}$ but a high mortality was also observed in the $10^{5}$ cells $\mathrm{ml}^{-1}$ treatment $(12.3$ and $3.7 \%$ survival at 24 and $48 \mathrm{~h}$ respectively). The polynomial regressions fitted were similar for both evaluation times (Fig. 1) with estimates of threshold concentrations of $10^{4.7}$ and $10^{4.5}$. Linear

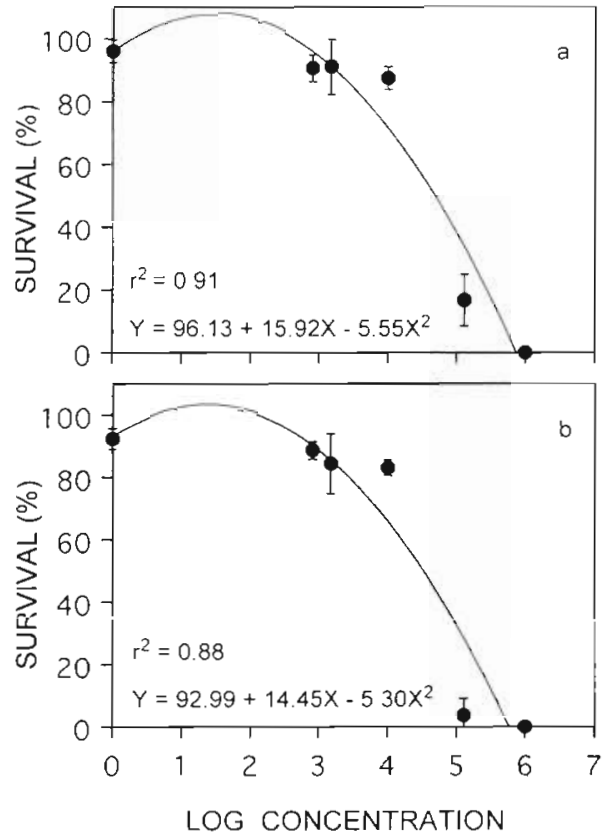

Fig. 1. Haliotis rufescens. Survival of larvae in different Vibrio alginolyticus concentrations after (a) $24 \mathrm{~h}$ and (b) $48 \mathrm{~h}$. Vertical bars are standard errors ( $\mathrm{n}=5$ ) and the solid tine is the fitted regression equation shown

Table 1. Analysis of variance for survival of Haliotis rufescens larvae after 24 h of exposure to 6 concentrations of Vibrio alginolyticus, including the effects due to linear and quadratic regressions

\begin{tabular}{|lrrrrr|}
\hline Source & df & \multicolumn{1}{c}{ SS } & \multicolumn{1}{c}{ MS } & $F$ & p \\
\hline Concentrations & 5 & 48847.05 & 9769.41 & 258.64 & $<0.001$ \\
$\quad$ Linear & 1 & 31037.21 & 31037.21 & 24.30 & $<0.025$ \\
Quadratic & 1 & 13978.84 & 13978.84 & 10.95 & $<0.050$ \\
Residual & 3 & 3831.00 & 1277.00 & & \\
Blocks & 4 & 49.72 & 12.43 & 0.33 & 0.855 \\
Error & 20 & 755.45 & 37.77 & & \\
Total & 29 & 49652.22 & & & \\
\hline
\end{tabular}

Table 2. Analysis of variance for survival of Haliotis rufescens larvae after $48 \mathrm{~h}$ of exposure to 6 concentrations of Vibrio alginolyticus, including the effects due to linear and quadratic regressions

\begin{tabular}{|lrrrrc}
\hline Source & df & \multicolumn{1}{c}{ SS } & \multicolumn{1}{c}{ MS } & $F$ & $p$ \\
\hline Concentrations & 5 & 48754.90 & 9750.98 & 476.83 & $<0.001$ \\
$\quad$ Linear & 1 & 30911.59 & 30911.59 & 18.10 & $<0.025$ \\
$\quad$ Quadratic & 1 & 12719.93 & 12719.93 & 7.45 & $>0.050$ \\
$\quad$ Residual & 3 & 5123.38 & 1707.80 & & \\
Blocks & 4 & 176.69 & 44.17 & 2.16 & 0.111 \\
Error & 20 & 408.99 & 20.45 & & \\
Total & 29 & 49340.58 & & & \\
\hline
\end{tabular}


effects were significant in both cases but quadratic effects were significant only at 24 h (Tables 1 \& 2). Before death, sick abalone larvae were unable to swim actively and remained on the bottom of containers.

The corresponding results for postlarval survival are shown in Fig. 2. Treatment effects were highly significant ( $p<0.001)$ and a significant block effect was observed at the 48 h evaluation ( $p=0.14$ ) (Tables $3 \& 4$ ) Threshold concentration estimates of $10^{46}$ and $10^{34}$ for 24 and $48 \mathrm{~h}$ respectively were obtained and there were stronger linear and quadratic effects at the second evaluation (Tables $3 \& 4$ ). Signs preceding postlarval death included inactivity and a weak attachment by the foot. Bacterial swarming was not observed, probably due to the low magnification used; however, a mucus-like aggregation attached to the foot of postlarvae was detected in high Vibrio alginolyticus concentrations.

\section{DISCUSSION}

This study shows that Vibrio alginolyticus can cause massive mortality in larvae of Haliotis rufescens within $24 \mathrm{~h}$ at concentrations above $10^{5}$ cells $\mathrm{ml}^{-1}$ (Fig. 1a). This toxic level is within the range of those reported for other mollusc species (Brown 1981, Jeffries 1982, Moore et al. 1993). However, a concentration of $10^{6}$ cells $\mathrm{ml}^{-1}$ is required to produce the same effect in abalone postlarvae (Fig 2a). This result is consistent with the increased resistance to bacterial infection by older larvae of the oyster Crassostrea virginica (Brown 1973).

The patterns of survival as a function of bacterial concentration at 24 and $48 \mathrm{~h}$ were similar for larvae (Fig 1) but not for postlarvae, which showed reduced survival in higher concentrations $\left(10^{4}\right.$ and $\left.10^{5}\right)$ at $48 \mathrm{~h}$ (Fig. 2). This resulted in different regression equations, a lower threshold bacterial concentration and an increased significance of linear and quadratic effects at 48 h (Fig. 2, Tables $3 \& 4$ ). The threshold levels estimated by the quadratic regressions should be considered as a first approximation despite the high coefficients of determination (Figs. 1 \& 2) since other alternative regression models were not tested.

It is difficult to explain the difference between postlarval survival at the 2 evaluation times. It might be due to the increase of bacterial concentration or toxins but these were not measured. Vibrio species can have very short generation times (12 to 20 min under optimal culture conditions) (Ulitzur 1974, Brown 1981). The lack of food during the $2 \mathrm{~d}$ experimental period probably was not an important factor since survival in controls was similar at both evaluation times (Fig. 2). In addition, recent studies suggest that Haliotis rufescens postlarvae can survive and develop at normal rates for

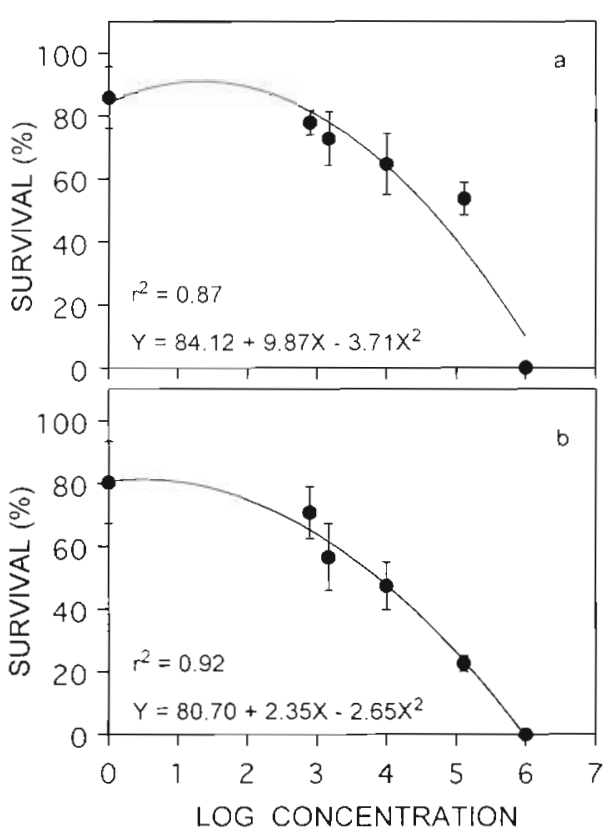

Fig. 2. Haliotis rufescens. Survival of postlarvae in different Vibrio alginolylicus concentrations after (a) $24 \mathrm{~h}$ and (b) $48 \mathrm{~h}$. Vertical bars are standard errors $(n=5)$ and the solid line is the fitted regression equation shown

Table 3. Analysis of variance for survival of Haliotis rufescens postlarvae after 24 h of exposure to 6 concentrations of Vibrio alginolyticus, including the effects due to linear and quadratic regressions

\begin{tabular}{lrrrrc|}
\hline Source & df & \multicolumn{1}{c}{ SS } & \multicolumn{1}{c}{ MS } & \multicolumn{1}{c}{$F$} & $\mathrm{p}$ \\
\hline Concentrations & 5 & 24044.14 & 4808.83 & 105.61 & $<0.001$ \\
$\quad$ Linear & 1 & 15780.44 & 15780.40 & 23.32 & $<0.025$ \\
Quadratic & 1 & 6233.75 & 6233.75 & 9.21 & $>0.050$ \\
$\quad$ Residual & 3 & 2029.95 & 676.65 & & \\
Blocks & 4 & 216.15 & 54.04 & 1.19 & 0.347 \\
Error & 20 & 910.72 & 45.54 & & \\
Total & 29 & 25171.01 & & & \\
\hline
\end{tabular}

Table 4. Analysis of variance for survival of Haliotis rufescens postlarvae after $48 \mathrm{~h}$ of exposure to 6 concentrations of Vibrio alginolyticus, including the effects due to linear and quadratic regressions

\begin{tabular}{|lrrrrc|}
\hline Source & df & \multicolumn{1}{c}{ SS } & \multicolumn{1}{c|}{ MS } & $F$ & p \\
\hline Concentrations & 5 & 22819.13 & 4563.83 & 98.78 & $<0.001$ \\
$\quad$ Linear & 1 & 19346.06 & 19346.10 & 204.93 & $<0.001$ \\
$\quad$ Quadratic & 1 & 3189.86 & 3189.86 & 33.79 & $<0.025$ \\
$\quad$ Residual & 3 & 283.21 & 94.40 & & \\
Blocks & 4 & 753.86 & 188.46 & 4.08 & 0.014 \\
Error & 20 & 924.04 & 46.20 & & \\
Total & 29 & 24497.03 & & & \\
\hline
\end{tabular}


at least $5 \mathrm{~d}$ after settlement in the absence of particulate food (Searcy-Bernal unpubl. data). However, a decreased postlarval resistance to bacterial infection after short-term starvation cannot be ruled out (Elston \& Lockwood 1983, Elston 1984)

An extrapolation of these results to predict the potential effect of Vibrio alginolyticus on larval or postlarval abalone aquaculture would depend on the actual concentration of this bacterium in the culture systems, and also on other culture conditions. Preliminary surveys in some Mexican abalone hatcheries suggest that levels of Vibrio spp. in larval culture systems rarely exceed $10^{3}$ cells $\mathrm{ml}^{-1}$, which would probably be harmless to larvae. However, their concentration in the postlarval microhabitat (i.e. biofilms on surfaces of culture systems) can be several orders of magnitude hıgher (LızárragaPartida unpubl. data). In addition, the co-occurrence of sub-optimal conditions of temperature or other environmental factors might have a synergistic effect, increasing Vibrio spp. pathogenicity (Elston 1984). For instance, Elston (1983) reported that one of these factors may be oxygen supersaturation, which can be extremely high in the postlarval microhabitat due to boundary layer conditions (Searcy-Bernal 1996)

Acknowledgements. Abalone larvae used in this study were donated by the commercial farm Abulones Cultivados, Eréndira, B.C., México. This research was partly funded by the Mexican government (CONACyT grants 3948A, 4023P-B and 5167T; SNI 5532) and the University of Baja California (UABC grant 4078-1). This work was part of the MS thesis research of C.A.-B. (CONACYT scolarship 52030).

\section{LITERATURE CITED}

Anguiano-Beltrán C (1996) Patogenicidad de Vibrio alginolyticus sobre larvas del mejillón europeo Mytilus galloprovincialis y larvas y postlarvas del abulón rojo Haliotis rufescens. MS thesis, CIC.ESE, Ensenada, BC, México

Brown C (1973) The effects of some selected bacteria on embryos and larvae of the American oyster, Crassostrea virginica. J Invert Pathol 21:215-223

Brown C (1981) A study of two shellfish pathogenic Vibrio strains isolated from a Log Island hatchery during a recent outbreak of disease. J Shellfish Res 1:83-87

Damon RA, Harvey WR (1987) Experimental design, ANOVA, and regression. Harper and Row, New York

Dixon MG. Hecht T, Brandt CR (1.991) Identification and treatment of a Clostridium and Vibrio infection in South African abalone, Haliotis midae L. J Fish Dis 14:693-695

Douillet PA, Langdon CJ (1993) Effects of marine bacteria on the culture of axenic oyster Crassostrea gigas (Thunberg) larvae. Biol Bull (Woods Hole) 184:36-51

Ebert EE (1992) Abalone aquaculture: a North American regional view. In: Shepherd SA, Tegner MJ, Guzmán del Proó SA (eds) Abalone of the world: blology, fisheries and culture. Blackwell Scientific, Oxford, p 570-582

Ebert EE, Houk JL (1984) Elements and innovations in the cultivation of red abalone Haliotis rufescens. Aquaculture 39:375-392
Elston R (1983) Histopathology of oxygen intoxication in the juvenile red abalone, Haliotis rufescens Swainson. J Fish Dis 6:101-110

Elston R (1984) Prevention and management of infectious diseases in intensive mollusc husbandry. J World Maricult Soc 15:284-300

Elston R, Leibovitz L (1980) Pathogenesis of experimental vibriosis in larval American oyster Crassostrea virginica. Can J Fish Aquat Sci 37:964-978

Elston R, Lockwood GS (1983) Pathogenesis of vibriosis in cultured juvenile red abalone. Haliotis rufescens Swainson J Fish Dis 6:111-128

Gherna R, Pienta P (eds) (1992) Catalogue of bacteria and bacteriofages, 18th edn. ATCC, Rockville, MD

Guillard RRL (1959) Further evidence of the destruction of bivalve larvae by bacteria. Biol Bull (Woods Hole) 117 $258-266$

Jeanthon C, Prieur D, Cochard JC (1988) Bacteriological survey of antibiotic-trcated sca water in a pecten maximus hatchery. Aquaculture 71:1-8

Jeffries VE (1982) Three Vibrio strains pathogenic to larvae of Crassostrea gigas and Ostrea edulis. Aquaculture 29 201-226

Lodeiros C, Bolinches J, Dopazo CP, Toranzo AE (1987) Bacillary necrosis in hatcheries of Ostrea edulis in Spain. Aquaculture 65:15-29

Mialhe E, Boulo V, Bachere E, Hervio D, Cousin K, Noel D Noel T, Ohresser M, le Deuff RM, Despres B, Gendreau S (1992) Development of new methodologies for diagnosis of infectious diseases in mollusc and shrimp aquaculture Aquaculture 107:155-164

Moore W, Anderson G, Manzi JJ (1993) Effects of the antibiotic oxytetracycline hydrochloride on Vibrio spp. bacteria in the larval an early postset culture of the hard clam Mercenaria mercenaria. World Aquacult 24:75-78

Murchelano RA, Brown C, Bishop J (1975) Quantitative and qualitative studies of bacteria isolated from sea water used in the laboratory culture of the American oyster, Crassostrea virginica. J Fish Res Bd Can 32:739-745

Pérez-Muñoz E (1995) El cultivo de abulón en México: desarrollo histórico, estado actual y sus perspectivas. BS thesis, Universidad Autónoma de Baja California, Ensenada

Searcy-Bernal R (1996) Boundary layers and abalone postlarval culture: prelminary studies. Aquaculture 140 $129-137$

Searcy-Bernal R, Salas-Garza AE, Flores-Aguilar RA (1992) Research in Mexico on the critical stage of abalone seed production. In: Shepherd SA, Tegner MJ, Guzmán del Próo $S$ (eds) Abalone of the world: biology, fisheries and culture. Blackwell Scientific, Oxford, p 547-560

Sindermann CJ (1988) Molluscan diseases. In: Sindermann CJ, Lightner DV (eds) Disease diagnosis and control in North American marine aquaculture. Elsevier, Amsterdam, p 266-31.6

Tubiash HS, Chanley PE, Leifson E (1965) Bacillary necrosis, a disease of larval and juvenile bivalve mollusks. J Bacteriol 90:1036-1044

Tubiash HS, Otto SV (1986) Bacterial problems in oysters: a review. In: Vivares CP, Bonami JR, Jasper E (eds) Pathology in marine aquaculture. European Aquaculture Society, Special Publ No. 8, Breden, p 233-242

Ulitzur $S(1974)$ Vibrio parahaemolyticus and Vibrio alginolyticus: short generation-time marine bacteria. J Microbiol Ecol 1:129-1.3.5

Walne PR (1958) The importance of bacteria in laboratory experiments on rearing the larvae of Ostrea edulis (L.). J Mar Biol Assoc UK 37:415-425 